Тригуб О. В., кандидат сільськогосподарських наук, Устимівська дослідна станція рослинництва Інституту рослинництва ім. В. Я. Юр'єва УААН

Ляшенко В. В., кандидат сільськогосподарських наук Полтавська державна аграрна академія

\title{
ЗАЛЕЖНІСТЬ ТРИВАЛОСТІ ФАЗ ВЕГЕТАЦЙНОГО ПЕРІОДУ У ГРЕЧКИ ВІД ПОГОДНО-КЛІМАТИЧНИХ ФАКТОРІВ СЕРЕДОВИЩА
}

\author{
Рецензент - доктор сільськогосподарських наук В. М. Писаренко
}

Мета статmi - вивчення тривалості вегетаційного періоду у гречки і його фаз в контрастних за параметрами тепло- $і$ вологозабезпечення умовах середовища.

Методика дослідження. Наведено результати аналізу селекиійного та місцевого матеріалу 156 сортів та форм гречки звичайної різного походження із Начіональної колекцї̈ Украӥни протягом 2014-2018 років в Устимівській дослідній станції рослинництва.

Результати дослідження. За результатами вивчення проведено розподіл скоростиглих та середньостиглих зразків на підгрупи за рівнем вираження показників та походження матеріалу. Крім рівня вираження ознаки, визначено і проаналізовано варіабельність тривалості основних міжфазних періодів у гречки та залежність їх від погодно-кліматичних умов (за рівнем гідро-термічного коефіцієнта). Для використання в селекиійних дослідженнях рекомендовано зразки із певних підгруп груп стиглості як базовий $і$ більш потенційно стабільний вихідний матеріал, а також визначено певні унікальні генотипи як потенційні джерела з генетично контрольованою тривалістю певних міжфазних періодів вегетачії. Потреба в такому матеріалі визначається необхідністю контролю за тривалістю фаз росту та розвитку рослин для уникнення чи протидії несприятливим факторам зовнішнього середовища і як приклад - можливістю використання різних агротехнічних прийомів при вирощуванні гречки (строки посіву, сорти різних термінів достигання тощзо).

Елементи наукової новизни. Порівняно тривалість фаз вегетаиійного періоду сортів та форм гречки за різних погодних умов із визначенням гідро-термічного коефіиієнта кожного міжфазного періоду росту i розвитку рослин. Встановлено статистичні параметри обумовленості прояву показників тривалості міжфазних періодів у різних за стиглістю сортів гречки.

Практична значущість. Виділено потенційно більш придатні для селекиійного використання сорти та місиеві форми в селекиії матеріалу з чітко контрольованими параметрами тривалості міжфазних вегетаційних періодів. Визначено унікальні за свойми характеристиками еталонні зразки гречки та рекомендовано їх як вихідний матеріал з різною тривалістю вегетачії, але досить значною їі стабільністю.

Ключові слова: гречка, тривалість вегетаційного періоду, гідро-термічний коефіцієнт, варіабельність, міжфазний період, джерела.

Тригуб Олег Володимирович - кандидат сільськогосподарських наук, вчений секретар, Устимівська дослідна станція рослинництва, Інститут рослинництва ім. В. Я. Юр'єва НААН України, вул. академіка Вавілова, 25, с. Устимівка, Глобинський район, Полтавська область, 39074, Україна, e-mail: udsr@ukr.net.

Ляшенко Віктор Васильович - кандидат сільськогосподарських наук, доцент, доцент кафедри рослинництва, Полтавська державна аграрна академія, вул. Сковороди, 1/3, м. Полтава, 36003, Україна, e-mail: viktor.liaschenko@pdaa.edu.ua, ORCID ID: 0000-0003-0177-6209.

Постановка проблеми. Отримання високих та стабільних урожаїв є головним завданням будь-якого сільськогосподарського виробника, вирішення якого залежить від потенціалу сорту чи гібриду та його реалізації у змінних умовах природного середовища 3 дотриманням відповідних технологій вирощування [7]. Гречка

значно поступається іншим культурам у реалізації свого природного потенціалу урожайності і навіть у найбільш сприятливі за погодними умовами роки вирощування іiі врожайність рідко перевищує 3,0 т/га [5]. Тому перед науковцями постало завдання - на основі дослідження генетичного різноманіття сучасних 


\section{СІЛЬСЬКЕ ГОСПОДАРСТВО. РОСЛИННИЦТВО}

сортів та форм, віднайти найбільш дієві механізми протидії або уникнення дії стресових факторів середовища [8].

Аналіз основних досліджень і публікацій, у яких розпочато розв'язання проблеми. Враховуючи досить короткий вегетаційний період гречки, до механізмів протидії умовам середовища можна віднести суто технологічні аспекти вирощування цієї культури - маніпулювання строками сівби для уникнення збігу найбільш критичних для формування урожаю періодів із несприятливими екстремальними характеристиками погодних умов [4], а також виділення із генофонду гречки генотипів, що мають максимально виражений потенціал швидкого формування зерна через компактність (дружність) цвітіння та зав'язування плодів i які мають більшу потенційну стійкість до захисту сформованого зерна від опадання в період наливу [2]. До потенційно привабливих 3 цієї точки зору можна віднести детермінантні та обмежено ростучі форми, які є більш скороспілими, але проблемою може стати збіг їх масового цвітіння через несприятливі погодні умови, що призведе до відсутності зав'язі i, як результат - до низького врожаю. Індетермінантні рослини поєднують фази росту із цвітінням та плодоутворенням, але це дає змогу період «цвітіння-плодоутворення» подовжити в часі і мати можливість формувати урожай після настання сприятливих для цього погодних умов.

Мета і завдання досліджень. Метою роботи передбачено вивчити тривалість вегетаційного періоду і його фаз у контрастних за параметрами тепло- і вологозабезпечення умовах середовища. При цьому було розв'язано низку завдань: порівняння тривалості фаз вегетаційного періоду сортів та форм гречки за різних погодних умов із визначенням гідро-термічного коефіцієнта (ГТК) кожного міжфазного періоду росту i розвитку рослин; встановлено статистичні параметри обумовленості прояву показників тривалості міжфазних періодів у різних за стиглістю сортів гречки; виокремлення із генетичного різноманіття сортів i форм, що вирізняються значною толерантністю до фізіологічно допустимих коливань умов середовища (кількісних характеристик температури та опадів) та мають стабільні показники тривалості вегетації та ї міжфазних періодів.

Матеріал і методи досліджень. Польові дослідження тривали протягом 2014-2018 років у науковій сівозміні Устимівської дослідної станції рослинництва Інституту рослинництва ім. В. Я. Юр'єва НААН в умовах відкритого грунту у колекційному розсаднику за загальноприйнятою технологією вирощування. Для визначення урожайних, продуктивних характеристик рослинного матеріалу та показників морфологічної будови і біологічних властивостей рослин застосовували методики: «Широкий уніфікований класифікатор роду Гречки (Fagopyrum esculentum Moench.)» [10] та «Методика проведення експертизи сортів гречки їсівної (Fagopyrum esculentum Moench) на відмінність, однорідність і стабільність» [6]. Статистичну обробку даних та кореляційний i дисперсійний аналізи проведено за методиками, викладеними Б. А. Доспєховим [3]. Площа облікової ділянки $5,4 \mathrm{~m}^{2}$ за трикратного повторення, міжряддя 0,45 м і кількості зерен 1,8 млн насінин на га.

Загалом для дослідження взято 156 сортів i форм гречки звичайної (Fagopyrum esculentum Moench.) 3 Національної колекції України походженням із 3 країн (України, Російської Федерації та Республіки Білорусь), як матеріал створений для умов найбільш подібних до основних гречкосіючих регіонів України. За стандарт використано сорт Українка.

Результати досліджень. Відповідно до вимог «Широкого уніфікованого класифікатора роду Гречки (Fagopyrum esculentum Moench.)» [10] колекційний матеріал за тривалістю вегетаційного періоду поділяється на 5 груп стиглості: дуже скоростиглі ( 65 діб), скоростиглі (66-75 діб), середньостиглі (76-85 діб), середньопізні (86-95 діб) та пізньостиглі ( $\geq 96$ діб). За результатами попереднього вивчення весь використовуваний у дослідженні колекційний матеріал було віднесено до двох груп - скоростиглі та середньостиглі.

Незважаючи на досить коротку тривалість вегетаційного періоду у гречки, необхідно враховувати, що це культури пізнього строку сівби через значну чутливість до низьких температур [5]. А тому в період посіву, більшість гречкосіючих регіонів відчувають недостачу вологи у грунті, а іноді й повітряні посухи. Також важливим під час вирощування гречки $є$ надзвичайна чутливість генеративних органів рослин (квіток і суцвіть) до високих температур i недостатня кількість вологості повітря в період цвітіння. Тому крім повного вегетаційного періоду в дослідженнях враховувалися найбільш виражені етапи розвитку гречки - проростання насіння, поява сходів, утворення листків, стебла, гілок, бутонів, формування i достигання насіння, які називають фенологічними фазами рослин. 
СІЛЬСЬКЕ ГОСПОДАРСТВО. РОСЛИННИЦТВО

\section{1. Дані погодно-кліматичних умов років дослідження (Устимівка, 2014-2018 рр.)}

\begin{tabular}{|c|c|c|c|c|c|c|c|}
\hline \multirow{2}{*}{ Показники } & \multirow{2}{*}{ Рік } & \multicolumn{6}{|c|}{ Місяці } \\
\hline & & Березень & Квітень & травень & червень & липень & серпень \\
\hline \multirow{6}{*}{$\begin{array}{l}\text { Середня тем- } \\
\text { пература пові- } \\
\text { тря, } \mathrm{t}^{\circ} \mathrm{C}\end{array}$} & 2014 & 7,0 & 11,2 & 19,7 & 20,5 & 24,1 & 24,0 \\
\hline & 2015 & 5,2 & 10,1 & 17,6 & 21,0 & 22,8 & 23,0 \\
\hline & 2016 & 4,4 & 13,7 & 16,9 & 21,5 & 24,1 & 22,8 \\
\hline & 2017 & 6,0 & 11,5 & 16,5 & 21,9 & 22,5 & 24,8 \\
\hline & 2018 & $-1,8$ & 13,8 & 20,3 & 22,2 & 23,8 & 26,0 \\
\hline & $\begin{array}{c}\text { середнє } \\
\text { багаторічне }\end{array}$ & 0,5 & 8,9 & 15,9 & 19,5 & 21,0 & 19,8 \\
\hline \multirow{5}{*}{$\begin{array}{l}\text { Середня тем- } \\
\text { пература на } \\
\text { поверхні гру- } \\
\text { нту, } \mathrm{t}^{\circ} \mathrm{C}\end{array}$} & 2014 & 8,0 & 13,9 & 24,0 & 23,8 & 29,1 & 24,4 \\
\hline & 2015 & 5,8 & 11,7 & 20,7 & 25,0 & 26,6 & 28,9 \\
\hline & 2016 & 5,5 & 15,4 & 19,6 & 25,4 & 29,0 & 25,8 \\
\hline & 2017 & 6,0 & 13,9 & 19,3 & 27,1 & 28,2 & 29,8 \\
\hline & 2018 & 0,4 & 14,8 & 24,1 & 27,6 & 29,3 & 30,3 \\
\hline \multirow{6}{*}{$\begin{array}{l}\text { Кількість опа- } \\
\text { дів, мм }\end{array}$} & 2014 & 12,8 & 31,2 & 63,1 & 50,2 & 50,0 & 48,1 \\
\hline & 2015 & 67,5 & 40,9 & 56,5 & 123,5 & 46,7 & 9,0 \\
\hline & 2016 & 59,8 & 35,9 & 89,5 & 59,1 & 37,5 & 65,6 \\
\hline & 2017 & 9,9 & 15,9 & 30,6 & 14,7 & 92,2 & 3,7 \\
\hline & 2018 & 103,9 & 9,8 & 27,7 & 31,8 & 47,9 & 3,2 \\
\hline & $\begin{array}{c}\text { середнє } \\
\text { багаторічне }\end{array}$ & 28,0 & 44,0 & 50,0 & 57,0 & 72,0 & 58,0 \\
\hline \multirow{6}{*}{$\begin{array}{l}\text { Вологість по- } \\
\text { вітря, \% }\end{array}$} & 2014 & 64 & 68 & 60 & 63 & 65 & 57 \\
\hline & 2015 & 74 & 63 & 61 & 68 & 68 & 56 \\
\hline & 2016 & 85 & 61 & 73 & 71 & 66 & 67 \\
\hline & 2017 & 72 & 57 & 60 & 57 & 65 & 64 \\
\hline & 2018 & 94 & 61 & 54 & 63 & 70 & 56 \\
\hline & $\begin{array}{c}\text { середнє } \\
\text { багаторічне }\end{array}$ & 81 & 72 & 66 & 69 & 69 & 69 \\
\hline
\end{tabular}

Джерело: авторські дослідження.

Тривалість окремих міжфазних періодів залежить від особливостей сорту, строків і способів сівби, живлення, догляду за посівами тощо. Вегетаційний період розвитку рослин гречки розподілено на чотири міжфазні періоди: «посівсходи» (5-7 діб), «сходи-цвітіння» (24-35 діб), «цвітіння-початок достигання» (30-35 діб), «початок-повне достигання зерна» (17-24 діб) [1,9].

Загалом умови 2014-2018 років дослідження були надзвичайно різноманітними за кількістю тепла та вологи протягом вегетації гречки, що значно вплинуло на одержані результати урожайних характеристик сортів та форм, а також дало змогу значною мірою оцінити вплив тривалості окремих періодів на загальний результат. Незважаючи на те що посів гречки здійснювали в III декаді квітня - I декаді травня, при проведенні характеристики погодних умов року вивчення, було враховано більш ранні періоди, починаючи із березня кожного року (особливо кількість опадів), оскільки запаси вологи у грунті на період посіву мають значний вплив на швидкість появи сходів, їх дружність та силу рослин на початкових етапах розвитку (таблиця 1). Погодні умови 2014 року були спекотними із меншою за середньобагаторічні дані кількістю опадів. Лише травень виявився дощовим, за 12 днів випало 63,1мм (за норми 50,0 мм). Зафіксована злива $з$ градом (1,0-1,2 см діаметр) 26 травня та градом до $3 \mathrm{~cm}$ діаметром - 13 липня (випало 28,4 мм опадів). 2015 рік також відзначався помірною, але жаркою погодою 3 надзвичайно нерівномірним розподілом опадів протягом вегетації. Більшими за норму в 2,5 рази були опади у березні та червні (67,5 та 123,5 мм). За 11 днів червня випало 123,5 мм опадів (за норми 57,0 мм). Липень та серпень відмічалися, як спекотні та сухі, особливо серпень коли випало 9,0 мм опадів, що на 49,0 мм менше за норму. Погодні умови 2016 року були теплими і вологими, крім липня, коли кількість опадів була вдвічі меншою від норми (37,5 проти 72 мм). 2017 рік був теплим та надзвичайно сухим. Лише в липні кількість опадів переважала середньобагаторічну норму, коли за 9 


\section{СІЛЬСЬКЕ ГОСПОДАРСТВО. РОСЛИННИЦТВО}

дощових дні випало 92,2 мм (інтенсивний дощ спостерігався 27 липня - 29,5 мм). Погода серпня була надзвичайно сухою і спекотною. Середня температура повітря становила $24,8^{\circ} \mathrm{C}$, на поверхні грунту $29,8^{\circ} \mathrm{C}$. За 2 дощових дні випало лише 3,7 мм (на 54,3 мм менше за норму). Погодні умови 2018 року були помірно теплими і надзвичайно сухими. Меншою за норму кількість опадів спостерігалася у всі, крім березня, місяці, а в травні їхня кількість склала $22 \%$ і в серпні лише 5,5\% від норми.

Загалом температурний режим та кількість вологи протягом вегетації гречки в роки дослідження були різноманітними від екстремальних до оптимальних. Враховуючи напрям досліджень, було також проаналізовано погодні умови міжфазних періодів, щоб з'ясувати вплив кліматичних факторів та їх тривалість. Зважаючи на те, що посів гречки ми проводили в кінці квітня на початку травня, в цей період потрібен був запас вологи у грунті та достатня кількість тепла. Температурні умови всіх років дослідження були сприятливими для отримання дружних сходів, але кількість вологи в 2014, 2017 та 2018 роках не відповідала потребі, що й призвело до подовження періоду «посів-сходи» на 2-3 доби. Сходи в ці роки були неодночасними та часто слабкими. Повні сходи відмічалися на 10-12 день після посіву, після випадання дощу. Міжфазний період «сходи-цвітіння» років досліджень за кількістю тепла відповідав оптимуму для росту і розвитку рослин гречки. Але кількість опадів у роки досліджень відрізнялися від оптимальних до екстремальних. Особливо посушливими були умови 2017 i 2018 років, коли сума опадів у травні була на 40 i $45 \%$, а в червні на 75 і $45 \%$ меншою від норми. Такі умови не сприяли нормальному перебігу ростових процесів у рослин через нестачу вологи у грунті та повітряні посухи. Погодні умови в період «цвітіння-початок достигання» у всі роки були 3 надмірними температурами (особливо в 2014, 2016 та 2018 роках) та, за виключенням 2017 року, зі значною недостачею вологи у грунті через відсутність опадів. 2014 року також відмічений град та шквальний вітер, що значно пошкодили рослини. Період «початок-повне достигання» у гречки, на відміну від інших міжфазних періодів, вимагає помірної кількості вологи (ближче до сухої) і теплої погоди. Збирання більшості зразків гречки проводили в кінці липня на початку серпня і лише деякий колекційний матеріал збирали в середині серпня. У більшос- ті років дослідження хоч і не оптимальні, але сприятливі погодні умови були відмічені в цей період, який характеризувався підвищеними температурами та майже повною відсутністю опадів у серпні 2015, 2017 та 2018 років.

Увесь досліджуваний матеріал (156 зразків та форм) було розподілено на групи залежно від тривалості вегетаційного періоду (відповідно екологогеографічного походження та класифікації А. С. Кротова [2]. До скоростиглих зразків віднесено зразки походженням із Республіки Білорусь (Гомельська, Могилівська, Мінська області) та Російської Федерації (Тверська, Вологодська, Орловська, Володимирська, Московська та Ярославська області), всього 64 зразки; до середньостиглих зразків матеріал із України (Полтавська, Харківська, Київська, Чернігівська, Львівська, Івано-Франківська, Дніпропетровська, Вінницька, Тернопільська, Сумська, Одеська та Хмельницька області) і Російської Федерації (Орловська, Курська, Кемеровська області та Республіки Башкортостан і Татарстан), всього 92 зразки.

Результати досліджень свідчать про значне різноманіття за показником тривалості вегетаційного періоду та проходження фаз вегетації всередині кожної з груп стиглості, тому було проведено розподіл цього матеріалу на підгрупи, до кожної з яких включено колекційні зразки за спільним походженням та подібним типом розвитку рослин і співставною тривалістю міжфазних періодів. Зразки скоростиглої групи поділено на 3 підгрупи: I - Могилівська, Гомельська і Мінська області; II - Вологодська, Ярославська і Тверська області; III - Московська, Володимирська і Орловська області. Зразки середньостиглої групи було розподілено на чотири підгрупи: I - Львівська, Івано-Франківська, Тернопільська та Хмельницька області; II - Полтавська та Харківська області; III - Одеська та Дніпропетровська області; IV - Київська, Сумська та Чернігівська області. Відповідно до такого розподілу на підгрупи було встановлено середні показники тривалості фаз вегетаційного періоду та всієї вегетації, а також розмах їх варіювання (таблиця 2). Також проведено математичний аналіз: розраховано гідро-термічний коефіцієнт, встановлено рівень варіювання показника тривалості вегетаційного періоду і його фаз та залежність його від рівня ГТК певного періоду (таблиці 3-5). 
СІЛЬСЬКЕ ГОСПОДАРСТВО. РОСЛИННИЦТВО

\section{2. Тривалість міжсфазних періодів у зразків гречки різних груп та підгруп стиглості (діб)} (за даними 2014-2018 років досліджень)

\begin{tabular}{|c|c|c|c|c|c|c|c|c|c|c|c|c|}
\hline \multirow{3}{*}{$\begin{array}{c}\text { Підгрупи } \\
\text { за стиглі- } \\
\text { стю }\end{array}$} & \multicolumn{12}{|c|}{ Міжфазні періоди } \\
\hline & \multicolumn{3}{|c|}{ «сходи- цвітіння» } & \multicolumn{3}{|c|}{$\begin{array}{c}\text { «цвітіння-початок } \\
\text { достигання» }\end{array}$} & \multicolumn{3}{|c|}{$\begin{array}{c}\text { «початок-повне } \\
\text { достигання» }\end{array}$} & \multicolumn{3}{|c|}{$\begin{array}{c}\text { «сходи-повне до- } \\
\text { стигання» }\end{array}$} \\
\hline & cep. & $\min$ & $\max$ & cep. & $\min$ & $\max$ & cep. & $\min$ & $\max$ & cep. & $\min$ & $\max$ \\
\hline \multicolumn{13}{|c|}{ Скоростигла група } \\
\hline $\mathrm{I}$ & 26 & 25 & 27 & 32 & 28 & 34 & 21 & 18 & 23 & 74 & 71 & 78 \\
\hline II & 27 & 26 & 28 & 30 & 28 & 32 & 20 & 18 & 22 & 73 & 69 & 75 \\
\hline III & 27 & 25 & 28 & 32 & 29 & 33 & 21 & 18 & 23 & 74 & 72 & 76 \\
\hline У групі & 27 & 25 & 28 & 31 & 28 & 34 & 20 & 18 & 23 & 74 & 69 & 78 \\
\hline \multicolumn{13}{|c|}{ Середньостигла група } \\
\hline $\mathrm{I}$ & 30 & 27 & 32 & 32 & 29 & 34 & 23 & 20 & 25 & 78 & 75 & 81 \\
\hline II & 28 & 27 & 29 & 31 & 29 & 33 & 22 & 19 & 24 & 75 & 72 & 80 \\
\hline III & 28 & 26 & 30 & 30 & 28 & 32 & 22 & 20 & 23 & 77 & 73 & 80 \\
\hline IV & 31 & 28 & 33 & 32 & 30 & 34 & 24 & 21 & 26 & 78 & 76 & 81 \\
\hline У групі & 30 & 26 & 33 & 31 & 28 & 34 & 23 & 19 & 26 & 77 & 72 & 81 \\
\hline
\end{tabular}

Джерело: авторські дослідження.

3. Вилив ГТК на тривалість міжфазного періоду «сходи-цвітіння" у скоростиглих зразків гречки

\begin{tabular}{|c|c|c|c|c|c|c|c|}
\hline Підгрупа & Рік & $\begin{array}{c}\sum \text { акт. тем- } \\
\text { ператур, } \\
>10^{\circ} \mathrm{C}\end{array}$ & $\begin{array}{c}\text { Сума } \\
\text { опадів, } \\
\text { мм } \\
\end{array}$ & ГТК & $\begin{array}{l}\text { Середнє у } \\
\text { групі, діб }\end{array}$ & $\begin{array}{c}\text { Коефіцієнт } \\
\text { варіації, } \\
\text { V, \% }\end{array}$ & $\begin{array}{l}\text { Коефіцієнт } \\
\text { кореляції, r }\end{array}$ \\
\hline \multirow[t]{6}{*}{ I } & 2014 & 397,5 & 50,9 & 1,28 & 27 & 21,1 & 0,58 \\
\hline & 2015 & 457,6 & 47,4 & 1,04 & 26 & 12,2 & 0,92 \\
\hline & 2016 & 422,5 & 72,2 & 1,70 & 26 & 17,4 & 0,63 \\
\hline & 2017 & 445,5 & 26,7 & 0,60 & 25 & 16,3 & 0,74 \\
\hline & 2018 & 527,8 & 24,0 & 0,45 & 26 & 18,2 & 0,68 \\
\hline & Xcep & 450,18 & 44,24 & 1,01 & 26 & 17,0 & 0,27 \\
\hline \multirow[t]{6}{*}{ II } & 2014 & $4 \quad 410,4$ & 52,9 & 1,26 & 28 & 21,0 & $0,0,48$ \\
\hline & 2015 & 446,1 & 45,1 & 1,01 & 28 & 17,7 & 0,66 \\
\hline & 2016 & 456,3 & 78,0 & 1,71 & 27 & 22,3 & 0,41 \\
\hline & 2017 & 452,0 & 26,6 & 0,59 & 26 & 18,7 & 0,68 \\
\hline & 2018 & 568,4 & 25,8 & 0,44 & 26 & 14,2 & 0,83 \\
\hline & Xcep & 466,64 & 45,68 & 1,00 & 27 & 18,8 & 0,40 \\
\hline \multirow[t]{6}{*}{ III } & 2014 & 4413,4 & 52,9 & 1,28 & 28 & 21,1 & $0,0,54$ \\
\hline & 2015 & 440 & 45,6 & 1,04 & 28 & 15,8 & 0,88 \\
\hline & 2016 & 446,3 & 80,5 & 1,80 & 27 & 19,4 & 0,67 \\
\hline & 2017 & 462,1 & 27,6 & 0,60 & 26 & 16,6 & 0,74 \\
\hline & 2018 & 578,2 & 25,8 & 0,44 & 25 & 16,3 & 0,77 \\
\hline & Xcep & 468,0 & 46,48 & 1,03 & 27 & 17,8 & 0,46 \\
\hline \multirow{6}{*}{$\begin{array}{l}\text { Середнє у } \\
\text { групі }\end{array}$} & 2014 & 408,1 & 52,2 & 1,27 & 28 & 21,1 & 0,47 \\
\hline & 2015 & 447,9 & 46,0 & 1,03 & 27 & 15,2 & 0,81 \\
\hline & 2016 & 441,7 & 76,9 & 1,74 & 27 & 19,7 & 0,70 \\
\hline & 2017 & 453,2 & 27,0 & 0,60 & 26 & 17,2 & 0,82 \\
\hline & 2018 & 558,1 & 25,2 & 0,45 & 26 & 16,2 & 0,86 \\
\hline & Xcep & 461,8 & 45,46 & 1,02 & 27 & 17,9 & 0,51 \\
\hline
\end{tabular}

Джерело: авторські дослідження. 
СІЛЬСЬКЕ ГОСПОДАРСТВО. РОСЛИННИЦТВО

4. Вилив ГТК на тривалість міжфазного періоду «цвітіння-початок достигання» у скоростиглих зразків гречки

\begin{tabular}{|c|c|c|c|c|c|c|}
\hline Підгрупа & $\begin{array}{c}\sum \text { акт. темпера- } \\
\text { тур, }>10^{\circ} \mathrm{C}\end{array}$ & $\begin{array}{c}\text { Сума опа- } \\
\text { дів, мм }\end{array}$ & ГТК & $\begin{array}{l}\text { Середнє у } \\
\text { групі, діб }\end{array}$ & $\begin{array}{c}\text { Коефіцієнт } \\
\text { варіації, V, \% }\end{array}$ & $\begin{array}{l}\text { Коефіцієнт } \\
\text { кореляції, r }\end{array}$ \\
\hline \multirow[t]{6}{*}{ I } & 574,0 & 45,3 & 0,83 & 28 & 16,9 & 0,72 \\
\hline & 630,0 & 119,5 & 1,90 & 34 & 27,6 & 0,14 \\
\hline & 731,0 & 64,8 & 0,89 & 30 & 22,8 & 0,53 \\
\hline & 700,8 & 14,7 & 0,21 & 34 & 20,0 & 0,51 \\
\hline & 690,2 & 30,4 & 0,44 & 32 & 18,3 & 0,61 \\
\hline & 665,2 & 54,94 & 0,85 & 32 & 21,1 & 0,12 \\
\hline \multirow[t]{6}{*}{ II } & 572,1 & 44,1 & 0,77 & 28 & 16,4 & 0,51 \\
\hline & 609,0 & 110,5 & 1,81 & 31 & 21,0 & 0,26 \\
\hline & 666,5 & 60,1 & 0,90 & 29 & 24,4 & 0,10 \\
\hline & 678,9 & 14,7 & 0,22 & 32 & 25,1 & 0,07 \\
\hline & 578,7 & 25,9 & 0,45 & 29 & 19,5 & 0,48 \\
\hline & 621,0 & 51,1 & 0,83 & 30 & 21,3 & 0,15 \\
\hline \multirow[t]{6}{*}{ III } & 594,5 & 46,9 & 0,79 & 32 & 20,3 & 0,38 \\
\hline & 651,0 & 122,5 & 1,88 & 33 & 18,4 & 0,44 \\
\hline & 719,5 & 64,0 & 0,89 & 31 & 22,2 & 0,26 \\
\hline & 700,8 & 14,7 & 0,21 & 29 & 17,6 & 0,64 \\
\hline & 670,9 & 29,5 & 0,44 & 33 & 16,4 & 0,73 \\
\hline & 667,3 & 55,5 & 0,84 & 32 & 19,0 & 0,38 \\
\hline \multirow{6}{*}{$\begin{array}{c}\text { Середнє } \\
\text { у групі }\end{array}$} & 580,8 & 45,4 & 0,80 & 29 & 17,9 & 0,46 \\
\hline & 630,0 & 119,5 & 1,90 & 33 & 22,0 & 0,18 \\
\hline & 705,7 & 63,3 & 0,90 & 30 & 23,1 & 0,21 \\
\hline & 693,5 & 14,7 & 0,21 & 32 & 20,9 & 0,35 \\
\hline & 646,6 & 27,3 & 0,42 & 31 & 18,1 & 0,40 \\
\hline & 651,3 & 54,0 & 0,85 & 31 & 20,5 & 0,11 \\
\hline
\end{tabular}

Джерело: авторські дослідження.

Аналізуючи дані таблиць 2-5, слід відзначити, що середня тривалість періоду «сходи-цвітіння» у зразках скоростиглої групи склала 27 діб з коливаннями в підгрупах від 26 до 27 діб. Міжфазний період «цвітіння-початок достигання» тривав 31 добу і варіював від 30 до 32 діб; період «початок-повне достигання» - 20 діб 3 коливанням 20-21 доба. Повний вегетаційний період «сходи-повне достигання» у скоростиглих зразків тривав 74 доби та змінювався в середньому за 2014-2018 роки у зразків підгруп від 73 до 74 діб. При цьому мінімальна тривалість вегетації у окремих зразків складала від 69 до 78 діб. Найбільш скоростиглими були зразки II підгрупи походженням з Вологодської,
Ярославської і Тверської областей - 73 доби (від 69 до 75) та дещо вищою у зразків III підгрупи (Московська, Володимирська i Орловська області) - 74 доби 3 незначним коливанням від 72 до 76 діб.

Серед сортів і форм скоростиглої групи найбільш стабільний період «сходи-цвітіння» мали зразки першої підгрупи $(\mathbf{V}=17,0 \%)$, а найбільшою різноманітністю вирізнявся матеріал другої $(\mathbf{V}=18,8 \%)$. При цьому для першої та III підгруп найбільш варіабельним був 2014 рік ( $\mathbf{V}=21,1 \%)$, а для II підгрупи - 2014 та 2016 роки (відповідно, $\mathbf{V}=21,0$ та 22,3\%). 
СІЛЬСЬКЕ ГОСПОДАРСТВО. РОСЛИННИЦТВО

\section{5. Вилив ГТК на тривалість міжфазного періоду «початок-повне достигання" у скоростиглих зразків гречки}

\begin{tabular}{|c|c|c|c|c|c|c|}
\hline Підгрупа & $\begin{array}{c}\sum \text { акт. темпе- } \\
\text { ратур, } \\
>10^{\circ} \mathrm{C}\end{array}$ & $\begin{array}{l}\text { Сума опа- } \\
\text { дів, мм }\end{array}$ & ГТК & $\begin{array}{l}\text { Середнє у } \\
\text { групі, діб }\end{array}$ & $\begin{array}{c}\text { Коефіцієнт ва- } \\
\text { ріації, V, \% }\end{array}$ & $\begin{array}{l}\text { Коефіцієнт } \\
\text { кореляції, r }\end{array}$ \\
\hline \multirow[t]{6}{*}{ I } & 482,0 & 32,5 & 0,67 & 20 & 13,7 & 0,51 \\
\hline & 410,8 & 27,1 & 0,66 & 18 & 16,5 & 0,44 \\
\hline & 506,1 & 25,4 & 0,50 & 21 & 18,9 & 0,30 \\
\hline & 495,1 & 65,4 & 1,32 & 22 & 14,6 & 0,51 \\
\hline & 547,4 & 35,5 & 0,65 & 23 & 21,1 & 0,34 \\
\hline & 488,3 & 37,2 & 0,76 & 21 & 17,0 & 0,25 \\
\hline \multirow[t]{6}{*}{ II } & 457,9 & 31,7 & 0,69 & 19 & 15,0 & 0,48 \\
\hline & 478,8 & 30,6 & 0,64 & 21 & 18,6 & 0,41 \\
\hline & 423,8 & 20,8 & 0,49 & 18 & 12,2 & 0,67 \\
\hline & 488,5 & 64,3 & 1,33 & 22 & 23,4 & 0,28 \\
\hline & 476,0 & 31,9 & 0,67 & 20 & 15,6 & 0,38 \\
\hline & 465,0 & 35,9 & 0,76 & 20 & 16,9 & 0,29 \\
\hline \multirow[t]{6}{*}{ III } & 463,1 & 30,9 & 0,67 & 19 & 14,6 & 0,62 \\
\hline & 504,6 & 34,3 & 0,68 & 22 & 18,9 & 0,39 \\
\hline & 433,8 & 21,7 & 0,50 & 18 & 21,1 & 0,22 \\
\hline & 517,6 & 68,4 & 1,32 & 23 & 14,6 & 0,58 \\
\hline & 513,6 & 35,1 & 0,68 & 22 & 17,9 & 0,44 \\
\hline & 486,5 & 38,1 & 0,77 & 21 & 11,3 & 0,70 \\
\hline \multirow{6}{*}{$\begin{array}{l}\text { Середнє } \\
\text { у групі }\end{array}$} & 467,7 & 31,7 & 0,68 & 19 & 14,4 & 0,57 \\
\hline & 463,7 & 30,7 & 0,66 & 20 & 18,0 & 0,49 \\
\hline & 454,6 & 22,6 & 0,50 & 19 & 17,4 & 0,52 \\
\hline & 499,7 & 66,0 & 1,32 & 22 & 17,5 & 0,46 \\
\hline & 512,3 & 33,9 & 0,66 & 22 & 18,2 & 0,37 \\
\hline & 479,6 & 37,0 & 0,77 & 21 & 15,1 & 0,34 \\
\hline
\end{tabular}

Джерело: авторські дослідження.

Залежність тривалості міжфазних періодів від погодно-кліматичних умов оцінювали за коефіцієнтом кореляції величини тривалості вегетації від гідро-термічного коефіцієнта (ГТК), який визначався як співвідношення кількості опадів (збільшене у 10 разів) за певний період до суми активних температур $\left(>10^{\circ} \mathrm{C}\right)$. Зразки всіх без виключення груп мали позитивну залежність тривалості вегетації від величини ГТК, але рівень залежності суттєво відрізнявся у підгрупах. У скоростиглої групи за періодом «сходи-цвітіння» - від r $=0,27$ у I підгрупи до $\mathrm{r}=46$ у III підгрупи; «сходи-початок достигання» - від $\mathrm{r}=0,12$ у I підгрупи до $\mathrm{r}=38$ у III підгрупи; «початок-повне достигання» - від $\mathrm{r}=0,25$ y I підгрупи до $\mathrm{r}=70$ у III підгрупи. В середньому у скоростиглої групи більш обумовленою погодними умовами була величина тривалості періодів «сходицвітіння» $(\mathrm{r}=0,51)$ та «початок-повне достигання» $(\mathrm{r}=0,34)$.

Дані таблиць 2, 6-8, описують кількісні характеристики міжфазних періодів, їх варіабельність та залежність від погодно-кліматичних умов років дослідження у зразків середньостиглої групи в розрізі років та за розподілу на підгрупи. Середня тривалість періоду «сходи-цвітіння» у зразків цієї групи була на рівні 30 діб зі зміною від 28 до 31 доби, при цьому окремі зразки мали тривалість від 26 до 33 діб. Меншим цей період виявлено у зразків III (Одеська та Дніпропетровська області) та II (Полтавська та Харківська області) підгруп. Міжфазний період «цвітіння-достигання» мав тривалість 31 доба і змінювався від 30 до 32 діб з варіюванням у підгрупах 28 (III підгрупа) до 34 (I та IV підгрупи) діб. Тривалість періоду «початок-повне достигання» у зразків варіював від 19 до 26 діб за середнього показника 23 доби (зі зміною в середньому по підгрупах від 22 до 24 діб). Показник «сходи-повне достигання» у зразків середньостиглої групи було виявлено на рівні 77 діб. Найбільш скоростиглими були сорти II підгрупи - середнє 75 діб (варіювання 72-80 діб), а найбільш пізньостиглими - I та IV підгруп - середнє 78 діб (варіювання 75-81 доба та 76-81 доба відповідно). 


\section{СІЛЬСЬКЕ ГОСПОДАРСТВО. РОСЛИННИЦТВО}

У середньостиглої групи міжфазний період «сходи-цвітіння» вирізнявся середнім рівнем варіабельності (V=21,3\%) зі зміною у підгрупах від $\mathbf{V}=18,8 \%$ у III до $\mathbf{V}=24,3 \%$ у I підгрупи. Період «цвітіння-початок достигання» мав середній рівень варіювання $\mathbf{V}=22,8 \%$ (від 22,0 до 24,1 \%) i період «початок-повне достигання» був ще менш варіабельним $\mathbf{V}=16,7$ \% (від 15,2 до 19,9 \%).

Щодо залежності від погодно-кліматичних умов років вирощування (за рівнем ГТК), то найбільша реакція на зміну температур і вологозабезпечення у всі міжфазні періоди відзначена у зразків III групи $\mathrm{r}=0,61,0,67$ та 0,70, походженням із Одеської та
Дніпропетровської областей. Найменше реагували на зміну умов зразки I підгрупи (Львівська, ІваноФранківська, Тернопільська та Хмельницька області), $r=0,24,0,30,0,18$. В середньому у зразків середньостиглої групи найбільше різноманіття в період «сходи-цвітіння» відзначено у 2017 році ( $\mathbf{V}=25,8 \%)$, періоду «цвітіння- початок достигання» - у 2015 та 2018 роках $(\mathbf{V}=24,4 \%)$, «початокповне достигання» у 2015 та 2017 роках ( $\mathbf{V}=17,9$ \%). Щодо залежності від рівня ГТК, більш чутливими були зразки в періоди «сходи-цвітіння» та «цвітіння-початок достигання» $-\mathrm{r}=0,61$ та $\mathrm{r}=0,62$.

6. Вилив ГТК на тривалість міжфазного періоду «сходи-цвітіння» у середньостиглих зразків гречки

\begin{tabular}{|c|c|c|c|c|c|c|c|}
\hline Підгрупа & Рік & $\begin{array}{c}\sum \text { акт. тем- } \\
\text { ператур, } \\
>10^{\circ} \mathrm{C}\end{array}$ & $\begin{array}{c}\text { Сума } \\
\text { опадів, } \\
\text { мм }\end{array}$ & ГТК & $\begin{array}{l}\text { Середнє у } \\
\text { групі, діб }\end{array}$ & $\begin{array}{l}\text { Коефіцієнт } \\
\text { варіації, } \\
\text { V, \% }\end{array}$ & $\begin{array}{l}\text { Коефіцієнт } \\
\text { кореляції, r }\end{array}$ \\
\hline \multirow[t]{6}{*}{ I } & 2014 & 546,0 & 57,0 & 1,04 & 32 & 20,1 & 0,64 \\
\hline & 2015 & 492,8 & 52,7 & 1,07 & 32 & 20,7 & 0,46 \\
\hline & 2016 & 456,3 & 78,0 & 1,71 & 28 & 18,4 & 0,73 \\
\hline & 2017 & 528,2 & 32,8 & 0,62 & 28 & 29,9 & 0,16 \\
\hline & 2018 & 649,6 & 29,6 & 0,46 & 27 & 32,6 & 0,09 \\
\hline & Xcep & 534,6 & 50,0 & 0,98 & 30 & 24,3 & 0,24 \\
\hline \multirow[t]{6}{*}{ II } & 2014 & 546,0 & 57,0 & 1,04 & 28 & 16,6 & 0,52 \\
\hline & 2015 & 465,2 & 50,8 & 1,09 & 27 & 18,4 & 0,40 \\
\hline & 2016 & 456,3 & 78,0 & 1,71 & 29 & 18,0 & 0,44 \\
\hline & 2017 & 498,5 & 30,6 & 0,61 & 27 & 20,5 & 0,27 \\
\hline & 2018 & 568,4 & 25,6 & 0,45 & 28 & 22,7 & 0,17 \\
\hline & Xcep & 506,9 & 48,4 & 0,98 & 28 & 19,2 & 0,40 \\
\hline \multirow[t]{6}{*}{ III } & 2014 & $\overline{516,5}$ & $\begin{array}{c}55,0 \\
\end{array}$ & 1,07 & 27 & 17,3 & $0,0,69$ \\
\hline & 2015 & 457,6 & 47,4 & 1,04 & 29 & 12,1 & 0,84 \\
\hline & 2016 & 469,9 & 83,4 & 1,78 & 30 & 19,7 & 0,51 \\
\hline & 2017 & 495,0 & 30,6 & 0,62 & 28 & 24,9 & 0,30 \\
\hline & 2018 & 585,0 & 25,6 & 0,44 & 26 & 20,2 & 0,32 \\
\hline & Xcep & 504,8 & 48,4 & 0,99 & 28 & 18,8 & 0,61 \\
\hline \multirow[t]{6}{*}{ IV } & 2014 & 575,5 & 259,1 & 1,03 & 29 & 19,0 & 0,61 \\
\hline & 2015 & 492,8 & 52,7 & 1,07 & 33 & 20,1 & 0,54 \\
\hline & 2016 & 540,8 & 83,4 & 1,54 & 32 & 24,7 & 0,31 \\
\hline & 2017 & 495,0 & 30,6 & 0,62 & 30 & 23,0 & 0,45 \\
\hline & 2018 & 668,4 & 32,2 & 0,48 & 28 & 27,6 & 0,14 \\
\hline & Xcep & 554,5 & 51,6 & 0,95 & 31 & 22,9 & 0,49 \\
\hline \multirow{6}{*}{$\begin{array}{l}\text { Середнє у } \\
\text { групі }\end{array}$} & 2014 & 546,0 & 257,0 & $1,1,04$ & 28 & 18,3 & 0,54 \\
\hline & 2015 & 477,1 & 50,9 & 1,07 & 30 & 17,8 & 0,67 \\
\hline & 2016 & 480,8 & 80,7 & 1,68 & 31 & 20,2 & 0,46 \\
\hline & 2017 & 504,2 & 31,2 & 0,62 & 27 & 24,6 & 0,33 \\
\hline & 2018 & 617,9 & 28,3 & 0,46 & 28 & 25,8 & 0,20 \\
\hline & Xcep & 525,2 & 49,6 & 0,97 & 30 & 21,3 & 0,61 \\
\hline
\end{tabular}

Джерело: авторські дослідження. 
СІЛЬСЬКЕ ГОСПОДАРСТВО. РОСЛИННИЦТВО

\section{7. Вилив ГТК на тривалість міжфазного періоду «цвітіння-початок достигання» у середньо-} стиглих зразків гречки

\begin{tabular}{|c|c|c|c|c|c|c|}
\hline Підгрупа & $\begin{array}{c}\sum \text { акт. темпе- } \\
\text { ратур, } \\
>10^{\circ} \mathrm{C}\end{array}$ & $\begin{array}{c}\text { Сума опа- } \\
\text { дів, мм }\end{array}$ & ГТК & $\begin{array}{l}\text { Середнє у } \\
\text { групі, діб }\end{array}$ & $\begin{array}{l}\text { Коефіцієнт } \\
\text { варіації, } \\
\text { V, \% }\end{array}$ & $\begin{array}{l}\text { Коефіцієнт } \\
\text { кореляції, r }\end{array}$ \\
\hline \multirow[t]{6}{*}{ I } & 610,1 & 50,2 & 0,82 & 33 & 20,2 & 0,55 \\
\hline & 609,0 & 119,3 & 1,96 & 34 & 26,4 & 0,31 \\
\hline & 731,2 & 57,6 & 0,79 & 29 & 16,7 & 0,82 \\
\hline & 752,7 & 26,2 & 0,35 & 30 & 25,8 & 0,35 \\
\hline & 767,2 & 34,6 & 0,45 & 33 & 21,1 & 0,50 \\
\hline & 694,0 & 34,6 & 0,45 & 32 & 22,0 & 0,30 \\
\hline \multirow[t]{6}{*}{ II } & 617,2 & 250,2 & 0,81 & 32 & 18,2 & $0,0,72$ \\
\hline & 588,3 & 104,8 & 1,78 & 33 & 24,8 & 0,31 \\
\hline & 710,3 & 57,6 & 0,81 & 29 & 20,3 & 0,47 \\
\hline & 716,1 & 24,3 & 0,34 & 30 & 21,6 & 0,40 \\
\hline & 725,1 & 34,6 & 0,48 & 32 & 28,7 & 0,22 \\
\hline & 671,4 & 54,3 & 0,84 & 31 & 22,7 & 0,35 \\
\hline \multirow[t]{6}{*}{ III } & 596,6 & 50,2 & 0,84 & 31 & 23,7 & 0,42 \\
\hline & 567,7 & 104,8 & 1,85 & 32 & 21,2 & 0,66 \\
\hline & 672,7 & 52,4 & 0,78 & 30 & 22,2 & 0,51 \\
\hline & 726,1 & 24,3 & 0,33 & 28 & 19,8 & 0,78 \\
\hline & 704,5 & 30,7 & 0,44 & 29 & 24,1 & 0,56 \\
\hline & 653,5 & 52,5 & 0,85 & 30 & 22,2 & 0,67 \\
\hline \multirow[t]{6}{*}{ IV } & 630,4 & 51,8 & 0,82 & 32 & 23,6 & 0,61 \\
\hline & 632,6 & 119,3 & 1,89 & 34 & 25,0 & 0,42 \\
\hline & 753,2 & 59,6 & 0,79 & 30 & 27,6 & 0,18 \\
\hline & 726,1 & 24,3 & 0,33 & 31 & 20,7 & 0,77 \\
\hline & 758,1 & 30,7 & 0,41 & 33 & 23,8 & 0,71 \\
\hline & 700,1 & 57,1 & 0,85 & 32 & 24,1 & 0,38 \\
\hline \multirow{6}{*}{$\begin{array}{l}\text { Середнє у } \\
\text { групі }\end{array}$} & 613,6 & 50,6 & 0,83 & 32 & 21,4 & 0,59 \\
\hline & 599,4 & 112,1 & 1,87 & 33 & 24,4 & 0,27 \\
\hline & 716,9 & 56,8 & 0,79 & 30 & 21,7 & 0,52 \\
\hline & 730,3 & 24,8 & 0,34 & 30 & 22,0 & 0,56 \\
\hline & 738,7 & 32,7 & 0,44 & 31 & 24,4 & 0,35 \\
\hline & 680,0 & 55,4 & 0,84 & 31 & 22,8 & 0,62 \\
\hline
\end{tabular}

Джерело: авторські дослідження.

Одним із головних завдань, які було розв'язано при проведенні роботи по дослідженню впливу рівня ГТК на тривалість вегетаційного періоду, є виявлення на основі математичних розрахунків потенційних регіонів походження матеріалу із більш стабільними параметрами тривалості вегетації зразків, а також виділення серед дослідженого набору сортів i форм, найбільш цінних зразків із певним рівнем тривалості повного вегетаційного періоду та його міжфазних періодів, і головно 3 високою стабільністю цих показників у різних погодних умовах. Виявлення та скринінг такого матеріалу дозволяє впровадити до селекції вихідний матеріал із генетично закріпленими параметрами за тривалістю вегетації, що потрібний при створенні сортів для різних напрямів використання, 3 контрольованими характеристиками протидії чи ухилення від впливу несприятливих погодних умов.

За періодом «сходи-цвітіння» заслуговують на увагу селекціонерів зразки I та III підгруп скоростиглої групи походженням із Могилівської, Гомельської і Мінської областей та Московської, Володимирської і Орловської областей. Зразки першої підгрупи мали тривалість цього періоду від 25 до 27 діб, коефіцієнт варіації величини показника склав $\mathbf{V}=17,0 \%$ (з розмахом від 12,2 до $21,1 \%$ ) за величини коефіцієнта кореляції з ГТК $\mathrm{r}=0,27$. У 


\section{СІЛЬСЬКЕ ГОСПОДАРСТВО. РОСЛИННИЦТВО}

третьої підгрупи тривалість цього періоду склала 27 діб 3 коливаннями від 25 до 28 діб за коефіцієнта варіації $\mathbf{V}=17,8 \%$ (3 розмахом 15,8-21,1\%) та коефіціснтом кореляції 3 величиною ГТК $\mathrm{r}=0,46$ (варіювання від 0,54 до 0,88). До найбільш цінного матеріалу за періодом «цвітіння-початок достигання» серед скоростиглих зразків можна віднести зразки I та II підгруп. У першої підгрупи період тривав 32 доби (з коливаннями від 28 до 34 діб) за коефіцієнта варіації $\mathbf{V}=21,1 \%$ та залежно від ГТК (за коефіцієнтом кореляції) $\mathrm{r}=0,12$ (з коливаннями від 0,14 до 0,61). Найбільшою цінністю за показником тривалості періоду «початокповне достигання» вирізнявся матеріал I підгрупи, який мав величину періоду 21 доба за коефіцієнта варіації $\mathbf{V}=17,0 \%$ та залежно від погодно-кліматичних умов на рівні $\mathrm{r}=0,25$ (3 коливаннями 0,30 до 0,51).

\section{8. Вилив ГТК на тривалість міжфазного періоду "початок-повне достигання» у середньостиглих зразків гречки}

\begin{tabular}{|c|c|c|c|c|c|c|}
\hline Підгрупа & $\begin{array}{c}\sum \text { акт. темпе- } \\
\text { ратур, } \\
>10^{\circ} \mathrm{C}\end{array}$ & $\begin{array}{c}\text { Сума опадів, } \\
\text { мм }\end{array}$ & ГТК & $\begin{array}{l}\text { Середнє у } \\
\text { групі, діб }\end{array}$ & $\begin{array}{l}\text { Коефіцієнт ва- } \\
\text { ріації, V, \% }\end{array}$ & $\begin{array}{l}\text { Коефіцієнт } \\
\text { кореляції, r }\end{array}$ \\
\hline \multirow[t]{6}{*}{ I } & 482,3 & 32,3 & 0,67 & 20 & 14,2 & 0,65 \\
\hline & 457,6 & 51,6 & 1,13 & 22 & 13,9 & 0,78 \\
\hline & 554,3 & 27,8 & 0,50 & 23 & 18,6 & 0,22 \\
\hline & 562,5 & 74,4 & 1,32 & 25 & 14,7 & 0,70 \\
\hline & 571,2 & 38,3 & 0,67 & 24 & 17,0 & 0,34 \\
\hline & 525,6 & 44,9 & 0,86 & 23 & 15,7 & 0,18 \\
\hline \multirow[t]{6}{*}{ II } & 448,2 & 32,2 & $0,0,72$ & 19 & 13,4 & $0,0,77$ \\
\hline & 438,6 & 51,6 & 1,18 & 23 & 16,5 & 0,32 \\
\hline & 571,6 & 29,6 & 0,52 & 21 & 16,7 & 0,24 \\
\hline & 578,6 & 74,4 & 1,29 & 24 & 16,6 & 0,36 \\
\hline & 534,6 & 35,4 & 0,66 & 23 & 13,0 & 0,69 \\
\hline & 514,3 & 44,6 & 0,87 & 22 & 15,2 & 0,44 \\
\hline \multirow[t]{6}{*}{ III } & 507,8 & 36,8 & 0,73 & 21 & 14,4 & 0,54 \\
\hline & 442,3 & 51,6 & 1,17 & 23 & 17,5 & 0,32 \\
\hline & 564,3 & 27,8 & 0,49 & 20 & 16,8 & 0,45 \\
\hline & 576,2 & 72,0 & 1,25 & 23 & 18,1 & 0,29 \\
\hline & 548,1 & 35,4 & 0,65 & 22 & 12,1 & 0,79 \\
\hline & 527,7 & 44,7 & 0,86 & 22 & 15,8 & 0,70 \\
\hline \multirow[t]{6}{*}{ IV } & 564,6 & 39,7 & 0,70 & 21 & 18,1 & $0,0,61$ \\
\hline & 438,6 & 51,6 & 1,18 & 25 & 23,6 & 0,37 \\
\hline & 587,1 & 29,6 & 0,50 & 24 & 17,9 & 0,78 \\
\hline & 594,8 & 78,0 & 1,31 & 26 & 20,1 & 0,49 \\
\hline & 597,0 & 40,2 & 0,67 & 23 & 19,8 & 0,57 \\
\hline & 556,4 & 47,8 & 0,87 & 24 & 19,9 & 0,50 \\
\hline \multirow{6}{*}{$\begin{array}{c}\text { Середнє у } \\
\text { групі }\end{array}$} & 500,7 & 35,3 & 0,70 & 21 & 15,0 & 0,71 \\
\hline & 444,3 & 51,6 & 1,16 & 23 & 17,9 & 0,34 \\
\hline & 569,3 & 28,7 & 0,50 & 21 & 17,5 & 0,42 \\
\hline & 578,0 & 74,7 & 1,29 & 24 & 17,9 & 0,35 \\
\hline & 738,7 & 37,3 & 0,51 & 24 & 15,0 & 0,77 \\
\hline & 566,2 & 45,5 & 0,83 & 23 & 16,7 & 0,27 \\
\hline
\end{tabular}

Джерело: авторські дослідження. 


\section{СІЛЬСЬКЕ ГОСПОДАРСТВО. РОСЛИННИЦТВО}

Найбільш стабільним серед групи середньостиглих зразків за період «сходи-цвітіння» відмічено матеріал II та III підгруп походженням із Полтавської та Харківської областей і Одеської та Дніпропетровської областей. Рівень вираження показника склав 28 діб за досить високої його стабільності (коефіцієнт варіації $\mathrm{V}=19,2$ та 18,8 \%). Зразки цих підгруп також мали середнього рівня взаємозв'язок із рівнем ГТК ( $\mathrm{r}=0,40$ та 0,61). За показником тривалості міжфазного періоду «цвітіння-початок достигання» найбільш цінний за величиною та стабільністю по роках матеріал мали зразки I та III підгруп - 32 та 30 діб ( $\mathrm{V}=22,0$ та 22,2 \%) за середнього рівня залежності від погодних умов (за ГТК) $-\mathrm{r}=0,30$ та 0,67 . Найбільш цінний матеріал серед зразків середньостиглої групи за тривалістю періоду «початок-повне достигання» формували зразки I підгрупи. Величина показника склала 23 доби за варіювання на рівні $\mathrm{V}=15,7 \%$ та низького коефіцієнта кореляції цього показника із величиною (ГТК) $\mathrm{r}=0,18$.

Дослідження широкого сортового матеріалу дозволило із групи вивчення виділити і окремі генотипи, що увиразнюються стабільними та найбільш витребуваними за величиною показниками. Переважна більшість це зразки із відзначених вище підгруп скоростиглої і середньостиглої груп, та матеріал деяких інших підгруп. До найбільш цінних скоростиглих зразків зі стабільним рівнем прояву всіх міжфазних періодів і вегетації в цілому належать: UC0100711, UC0100734, UC0101780, UC0101807, UC0101816 із Гомельської області, UC0100286, UC0100387, UC0101189, UC0101195, UC0101989, UC0101685 із Мінської області, UC0101878, UC0101880 iз Вологодської області, UC0100017, UC0100790, UC0100807, UC0101111 із Московської області, UC0100211, UC0100835, UC0100851, UC0101034, UC0101092, UC0101113, UC0101130 із Орловської області. Серед зразків середньостиглої групи за величиною та стабільним проявом у різні роки вивчення було виділено матеріал із Полтавської області - UC0100117, UC0100154, UC0100166, UC0100309, UC0100314, UC0100443, UC0100448, UC0100906, UC0100953, UC0100995, UC0101002, UC0101033, UC0101046, UC0101202, UC0101721, UC0101936, UC0101950; Харківської області - UC0100596, UC0100608, UC0100616, UC0100628, UC0101097; Одеської області - UC0100941, UC0101889, UC0101892, UC0102172; Львівської області - UC0100883, UC0100886, UC0101699, UC0101726, UC0101849, UC0101853; Хмельни- цької області - UC0100347, UC0100348, UC0100506, UC0100942, UC0101008, UC0101119, UC0101122, UC0101124, UC0101155, UC0101157, UC0101179, UC0101200, UC0101215, UC0101322, UC0101378, UC0101449, UC0101630, UC0101711, Тернопільської області UC0100653, UC0100658, UC0100672, $\mathrm{UC0101730.} \mathrm{До} \mathrm{унікальних} \mathrm{зразків} \mathrm{із} \mathrm{інших} \mathrm{під-}$ груп належать зразки - UC0100079, UC0101199, UC0101676, UC0101998 із Київської області та UC0100628, UC0100637, UC0100501, UC0100669, UC0101515, UC0101694 is Сумської області.

Висновок. Одержані дані в результаті дослідження 156 колекційних зразків скоростиглої і середньостиглої груп гречки дозволяють провести чітку диференціацію наявного генофонду за показниками тривалості вегетаційного періоду та його фаз у середині кожної із груп та науково обгрунтувати розподіл цього матеріалу на підгрупи залежно від його походження та рівня вираження досліджуваних ознак. У середині скоростиглої групи сформовано три, а середньостиглої - чотири підгрупи. Зразки цих підгруп мають чітку різницю за тривалістю проходження різних періодів росту і розвитку рослини та реалізації іiї генетичного потенціалу. Результати досліджень рівня варіабельності ознак (за коефіцієнтом варіаціi) та залежності їх від погоднокліматичних умов (за рівнем гідро-термічного коефіцієнта) дозволило виділити потенційно більш придатні для селекційного використання сорти і місцеві форми в селекції матеріалу з чітко контрольованими параметрами тривалості міжфазних вегетаційних періодів. Із скоростиглої групи за величиною і стабільністю періоду «сходи-цвітіння» кращими є зразки I та III підгруп, походженням із Могилівської, Гомельської, Мінської, Московської, Володимирської і Орловської областей, за тривалістю періоду «цвітіння-початок достигання» - I та II груп із Могилівської, Гомельської, Мінської, Вологодської, Ярославської і Тверської областей, за тривалістю періоду «початок-повне достигання»I підгрупи із Могилівської, Гомельської, та Мінської областей. У селекції середньостиглих сортів для формування стабільного за тривалістю періоду «сходи-цвітіння» матеріалу більш доцільно використовувати сорти та місцеві форми II та III підгруп походженням із Полтавської, Харківської, Одеської та Дніпропетровської областей; для періодів «цвітіння-початок достигання» та «початок-повне достигання» - крім попередніх ще й матеріал I підгрупи із Львівської, Іва- 
но-Франківської, Тернопільської та Хмельницької областей.

Крім загальногрупових закономірностей iз формування стабільних за тривалістю періодів вегетації, із досліджуваного матеріалу було виділено унікальні за своїми характеристиками зразки і рекомендовано їх як вихідний матеріал iз різною тривалістю вегетації, але досить знач-

\section{БІБЛІОГРАФІЯ}

1. Алексеєва О. С., Тараненко Л. К., Малина М. М. Генетика, селекція і насінництво гречки. Київ : Вища школа, 2004. 213 с.

2. Генофонд и селекция крупяных культур. Гречиха / Авт. колл. : Фесенко Н. В., Фесеанко Н. Н. и др. ; под ред. В. А. Драгавцева. СанктПетербург : ГНЦ РФ ВИР, 2006. 196 с.

3. Доспехов Б. А. Методика полевого опыта. Москва : Колос, $1979.416 \mathrm{c.}$

4. Ефименко Д. Я., Барабаш Г. И. Гречиха. Москва : ВО Агропромиздат, 1990. 192 с.

5. Культура гречихи : у 3 ч. Ч.1. История культуры, ботанические и биологические особенности / Авт. колл. : Алексеева Е. С., Малина М. М. и др. Каменец-Подольский : Издатель Мошак М. И., 2005. 192 с.

6. Методика проведення експертизи сортів гречки їстівної (Fagopyrum esculentum Moench)

\section{REFERENCES}

1. Alekseieva, O. S., Taranenko, L. K., Malyna, M. M. (2004). Henetyka, selektsiia $i$ nasinnytstvo hrechky [Genetics, selection and seedling of buckwheat]. Kyiv: Vyshcha shkola [In Ukrainian].

2. Fesenko, N. V., Feseanko, N. N., Romanova, O. I., Alekseeva, E. S., Suvorova, G. N. (2006). Genofond i selekcija krupjanyh kul'tur. Grechiha [Genetic fund and selection of cereals. Buckwheat]. V. A. Dragavceva (Ed.). SanktPeterburg: GNC RF VIR [In Russian].

3. Dospehov, V. A. (1979). Metodika polevogo opyta [Field experiment technique]. Moskva : Kolos [In Russian].

4. Efimenko, D. Ja., Barabash, G. I. (1990). Grechiha [Buckwheat]. Moskva : VO Agropromizdat [In Russian].

5. Alekseeva, E. S. (Eds.) (2005). Kul'tura grechihi : 43 ch. [Buckwheat culture: 3 vols.]. (Vol. 1) Istorija kul'tury, botanicheskie $i$ biologicheskie osobennosti [History of culture, botanical and biological features]. KamenecPodol'skij: Izdatel' Moshak M. I. [In Russian].

6. Metodyka provedennia ekspertyzy sortiv hrechky yistivnoi (Fagopyrum esculentum Moench) ною іiї стабільністю. До таких еталонних зразків серед середньостиглого матеріалу було віднесено сорти та місцеві форми із Полтавської, Хмельницької, Львівської, Тернопільської, Харківської, Київської та Сумської областей. Із скоростиглого матеріалу заслуговують на увагу сорти та форми із Гомельської, Мінської, Вологодської, Московської та Орловської областей.

на відмінність, однорідність і стабільність. URL : http://sops.gov.ua/pdfbooks/Metodiki/8.pdf (дата звернення: 22.02 .2019 р.).

7. Січкар B. I. Селекційна цінність колекційних зразків при створенні високопродуктивних сортів сої. Селекиія і насінництво. 2014. Вип. 106. C. 83-92.

8. Тараненко Л. К., Яцุишен О. Л. Принципи, методи і досягнення селекції гречки (Fagopyrum esculentum Moench.). Вінниця : ТОВ «НіланЛТД», 2014. 222 c.

9. Тараненко Л.К. Генетическое обоснование совершенствования методов селекции гречихи Fagopyrum esculentum Moench : дис. д-ра биолог. наук : 06.01.05. Харьков, 1989. 383 c.

10. Широкий уніфікований класифікатор роду Гречки (Fagopyrum Mill.) / Тригуб О. В. та ін. Устимівка, 2013. 54 с.

na vidminnist, odnoridnist i stabilnist [The method of examination of edible buckwheat varieties (Fagopyrum esculentum Moench) for difference, homogeneity and stability]. Retrieved from: http://sops.gov.ua/pdfbooks/Metodiki/8.pdf

[In Ukrainian].

7. Sichkar, V. I. (2014). Selektsiina tsinnist kolektsiinykh zrazkiv pry stvorenni vysokoproduktyvnykh sortiv soi [Selection value of collection samples when creating high-yielding soy varieties]. Selektsiia i nasinnytstvo, 106, pp. 83-92 [In Ukrainian].

8. Taranenko, L. K., Yatsyshen, O. L. (2014). Pryntsypy, metody i dosiahnennia selektsii hrechky (Fagopyrum esculentum Moench.) [Principles, methods and achievements of selection of buckwheat (Fagopyrum esculentum Moench.)]. Vinnytsia: TOV «Nilan-LTD» [In Ukrainian].

9. Taranenko, L. K. (1989). Geneticheskoe obosnovanie sovershenstvovanija metodov selekcii grechihi Fagopyrum esculentum Moench [Genetic substantiation of the improvement of buckwheat breeding methods Fagopyrum esculentum Moench]. Doctor's thesis. Har'kov [In Russian]. 


\section{СІЛЬСЬКЕ ГОСПОДАРСТВО. РОСЛИННИЦТВО}

10. Tryhub, O. V., Kharchenko, Yu. V., Riabchun, V. K., Hryhorashchenko, L. V., Dokukina, K. I. (2013). Shyrokyi unifikovanyi klasyfikator rodu Hrechky (Fagopyrum Mill.) [Wide unified classifier of the genus Buckwheat (Fagopyrum Mill.)]. Ustymivka [In Ukrainian].

Тригуб О. В., Лященко В. В. Зависимость продолжсительности фаз вегетационного периода у гречихи от погодно-климатических факторов среды

Цель статьи - изучение продолжительности вегетационного периода и его фаз в контрастных по параметрам тепло- и влагообеспечения условиях среды.

Методика исследования. Приведены результаты анализа селекиионного и местного материала 156 сортов и форм гречихи обыкновенной различного происхождения из Национальной коллекции Украины на протяжении 2014-2018 годов в Устимовской опьтной станиии растениеводства.

Результаты исследования. По результатам изучения проведено распределение скороспельх и среднеспельх образиов на подгруппы по уровню выражения показателей и происхождения материала. Кроме уровня выражения признака, определена и проанализирована вариабельность продолжительности основных межфазных периодов у гречихи и зависимость их от погодно-климатических условий (по уровню гидро-термического коэфичиента). Для использования в селекиионных исследованиях рекомендованы образцы из выбранных подгрупп спелости, как базовый и потенциально стабильный исходный материал, а также определены уникальные генотипы как потенциальные источники с генетически контролируемой продолжительностью определённых межфазных периодов вегетаиии. Потребность в таком материале обусловливается необходимостью контроля за продолжительностью фаз роста и развития растений для ослабления влияния или противодействия неблагоприятным факторам внешней среды и как пример - возможность использования различных агротехнических приёмов при выращивании гречихи (сроки посева, сорта различных сроков созревания и т.д.).

Элементы научной новизны. Проведены сравнения продолжительности фаз вегетационного периода сортов и форм гречихи при различных погодных условиях с определением гидротермического коэффиииента каждого межфазного периода роста и развития растений. Установлены статистические параметры обусловленности проявления показателей продолжительности межфазных периодов в различных по зрелости сортов гречихи.

Практическая значимость. Выделены потенциально более пригодные для селекиионного использования сорта гречихи и местные формы в селекиии материала с четко контролируемыми параметрами продолжстельности межфазных вегетационных периодов. Определены уникальные по своим характеристикам эталонные образиы гречихи и рекомендованы как исходный материал с разной продолюительностью вегетации, но весьма значительной ее стабильностью.

Ключевые слова: гречка, продолжительность вегетационного периода, гидротермический коэффициент, вариабельность, межфазный период, источники.

Тригуб Олег Владимирович - кандидат сельскохозяйственных наук, ученый секретарь, Устимовская опытная станция растениеводства, Институт растениеводства им. В. Я. Юрьева НААН Украины, ул. академика Вавилова, 25, с. Устимовка, Глобинский район, Полтавская область, е-mail: udsr@ukr.net.

Ляшенко Виктор Васильевич - кандидат сельскохозяйственных наук, доцент, доцент кафедры растениеводства, Полтавская государственная аграрная академия, ул. Сковороды, 1/3, г. Полтава, 36003, Украина, e-mail: viktor.liaschenko@pdaa.edu.ua, ORCID ID: 0000-0003-0177-6209.

Tryhub $O . V$., Liashenko $V . V$. The dependence of the phases' duration of buckwheat growing period on the environmental weather-climatic factors

The aim of the article is studying the duration of the growing period and its phases in contrasting environmental conditions concerning heat and moisture provision.

Methods of the research. The analysis results of the selection and local material of 156 buckwheat varieties and forms of various origin from the National Collection of Ukraine during 2014-2018 in the Ustymivka experimental station of plant growing gave been presented.

The research results. According to the results of the study, the early-and mid-ripening samples were distributed into subgroups according to the level of expressing indicators and the origin of the material. In ad- 
dition to the level of expressing the trait, the variability of the duration of the main interphase periods in buckwheat and their dependence on weather and climatic conditions (according to the level of hydrothermal coefficient) were determined and analyzed. For using in breeding researches, the samples from definite subgroups of ripening were recommended as basic and potentially more stable parent material, and also certain unique genotypes were identified as potential sources with genetically controlled duration of certain interphase vegetation periods. The need in such material is determined by the necessity of controlling the duration of plant growth and development phases to eliminate the influence or counteraction to unfavorable environmental factors and, as an example, the possibility of using various agro-technical methods for growing buckwheat (sowing time, varieties of different ripening time, etc.).

The elements of scientific novelty. The duration of the vegetation period phases of buckwheat varieties and forms at different weather conditions with defining the hydro-thermal coefficient of each interphase plant growth and development period have been compared. The statistical parameters of stipulating the manifestation of the interphase periods' duration indices in different buckwheat varieties concerning their ripening qualities were established.

Practical importance. Potentially more suitable varieties for breeding and the local forms in the selection material with strictly controlled parameters of interphase vegetation periods' duration were distinguished. The unique standard samples of buckwheat as to their characteristics were determined and recommended as a parent material with different vegetation duration, but rather considerable stability.

Key words: buckwheat, duration of vegetation period, hydro-thermal coefficient, variability, interphase period, sources.

Tryhub Oleh Volodymyrovych - Candidate $(\mathrm{PhD})$ of Agricultural Sciences, Scientific secretary, Ustymivka experimental station of plant growing of the Institute of Plant growing named after V. Ya. Yuriev of NAAS of Ukraine, 25, akademician Vavylova st., v. Ustymivka, Hlobyno district, Poltava region, 39074, Ukraine, e-mail: udsr@ukr.net.

Liashenko Viktor Vasylovych - Candidate $(\mathrm{PhD})$ of Agricultural Sciences, Associate Professor at the Department of Selection, Seed Breeding, and Genetics of Poltava State Agrarian Academy, 1/3, Skovorody st., Poltava, 36000, Ukraine, e-mail: viktor.liaschenko@pdaa.edu.ua, ORCID ID: 0000-0003-0177-6209.

Стаття надійшла до редакції 01.03.2019 р.

Бібліографічний опис для цитування :

Тригуб О. В., Ляменко В. В. Залежність тривалості фаз вегетаційного періоду у гречки від погоднокліматичних факторів середовища. Вісник ПДАА. 2019. № 1. С. 94-107.

DOI 10.31210/visnyk2019.01.11

(С) Тригуб Олег Володимирович, Ляменко Віктор Васильович, 2019 